\title{
Mainstreaming Modernisation Risk Politics in Indonesia's Democratisation: Towards Public Control of Welfare and Risk in Expanding Water Access
}

\author{
Tadzkia Nurshafira ${ }^{1}$
}

Received: 26 September 2018 | Accepted: 31 December 2018 | Published: 11 January 2019

\begin{abstract}
This paper explores how modernisation risk politics are understood and situated in Indonesia's democratisation, specifically in the issue of clean water provision. Taking water procurement and the expansion of palm oil industries in Pandeglang District as its case study, this paper endeavours to identify the politics of knowledge between local communities and the government in defining and minimising modernisation risks under the democratic regime. Informed by the notions of risk society introduced by Ulrich Beck (1992), dispositif by Michel Foucault (Foucault \& Gordon, 1977), and transformative democracy by Harris, Stokke, \& Törnquist (2004) and Törnquist \& Warouw (2009), this article argues that certain knowledge of risk shapes and conditions existing democratic institutions and actors' will-capacity in expanding water access. That means that the calculation of risk is strongly influenced by the politics of knowledge, including in identifying what is considered 'risk', as well as what is considered 'agent' and 'institution' relevant to minimising the impact of risk. The politics of knowledge represents the contestation between certain risk dispositif and its alternative, which embodies the exercise of power and is followed by certain technologies of government as material embodiments of such rationality.
\end{abstract}

Keywords: modernisation risk; transformative democracy; dispositif; clean water; palm oil industries

\section{Introduction}

Issues of unequal access to affordable, safe, and sustainable water continue to characterise the distribution of welfare in Indonesia. This condition affects those who are living in both rural and urban areas, leading to low quality of life and livelihood, especially for the poor. While some areas have encountered problems of water

Tadzkia Nurshafira is a research assistant at the Institute of International Studies (IIS). She obtained her bachelor's degree in 2017 from the Department of International Relations at the Universitas Gadjah Mada. Her research interests cover the political economy of development, the political economy of global environmental change, and water politics. 
abundance, others have suffered from the limited availability of clean water for drinking and sanitation purposes. This problem of water shortage has received great attention from the national government and has been institutionalised in Indonesia's National MediumTerm Development Plan 2015-2019. The government has set a target of " $100-0-100 "-100 \%$ access to drinking water, $0 \%$ slums, and $100 \%$ proper sanitation - in 2019. However, based on the interim evaluation of the plan, water access coverage only reached $71.14 \%$ in 2016. Conflicting interests and perceptions between government, local communities, and private water providers regarding access to water; the absence of institutionalisation for local water access initiatives; and the absence of regulatory frameworks that adequately manage and evaluate private sector and industrial participation in the water delivery process have been important issues.

The shortage of clean water has also affected Pandeglang District, Banten Province. This area is located near Jakarta, Indonesia's capital city, yet its rural areas continue to have difficulty gaining gain sustainable access to water. The Regional Water Utility Company (Perusahaan Daerah Air Minum/PDAM) system only covers $9.8 \%$ of Pandeglang's total area, covering mostly urban areas, and has yet to reach the southern part of the district. While rural communities in Pandeglang have always had to deal with geographical contours that constrain their use of water springs, massive oil palm plantations have contributed to and even exacerbated the condition. Especially since 1996, plantations have been the main causes of water shortages due to their massive operations and lack of contribution to local clean water procurement. The issues has led local communities to increased risks of water shortages and impacted their basic quality of life.

In regards to this condition, this article attempts to analyse the problems of risk caused by a lack of water access during Indonesia's reform era. This article endeavours specifically to understand water risk politics under the expansion of the palm oil industry, which has led to numerous socio-economic conflicts. Taking Pandeglang as a 
case study, this paper further aims to capture the dynamics of public service and distribution of welfare, which are broadly situated by the commodification of water and the expansion of land-based capitalism through oil palm plantations, creating uneven access to and poor quality of water.

This paper intends to posit water shortage as representing the problems of welfare distribution and public service reform in Indonesia over the last 20 years. While the lack of sustainable and safe access to water affects local communities' basic quality of life and hampers them in maximising their potential as human resources, welfare reform has been unable to address the problem of water unaffordability and address local communities' individual problems in several areas. As such, instead of perceiving water problems as isolated cases, it is most fruitful to contextualise the issues in their structural roots in the problem of welfare reform. In this light, such issues highly characterise democratisation in Indonesia. Demand for basic needs provision have been expressed in numerous ways through democratic movements and institutions. The notion of a 'welfare state' has grown increasingly in correspondence to massive public enthusiasm for a more prosperous life. Welfare issues, including water and sanitation needs; health services; education, security, transportation, and housing systems; are increasingly perceived as 'public issues' popularised by the electoral democracy process. That said, the state has been seen as a 'duty bearer' responsible for providing public services, and is expected to craft adequate regulations as well as policies to institutionalise this responsibility. As presumed, this would guarantee the equal implementation of public service provisions. The rise of the welfare narrative within the practice of democracy marks a gap, the absence of a substantial dimension of democracy that had previously been neglected by existing mainstream implementations.

Despite improvements in institutionalisation through rule of law and through regulations, the issues of welfare distribution has increasingly been the source of populism in Indonesian politics. 
Populism and welfare have become inseparable, and turned out to prominently characterise Indonesia's democratisation. Dominant actors, seeking to appear as 'alternative actors', manage to use populist approaches and charisma to mobilise public support. The mainstreaming of populism is inevitable, due to the declining role of clientelism (Samadhi \& Warouw, 2009) in winning elections. Candidates are in need of greater mass bases and support-a gap that populism can address, as it opens space for reaching out to the broader public through campaigns on welfare issues. At the same time, the welfare narrative both directs and strengthens the tendency to build collective issues in society. As such, the issues of welfare in general and the distribution of wealth in particular are at stake in Indonesia's democratisation, able to initiate movement using both the top-down and the bottom-up approaches.

However, the distribution of wealth, following Ulrich Becks' (1992) account, is prominent in modernity and industrial society. The production and distribution of wealth brought about by modernisation and technological productivity has been systematically accompanied by the social production of risk (Beck, 1992). Modernisation, characterised mostly by massive development programmes in Indonesia and elsewhere, brought about massive changes to society. That said, it is precisely the achievement of industrial modernity in the fight against poverty, material misery, and wealth distribution that has led to risk society, meaning that Indonesia must deal with the side effects of modernity (Sørensen, 2018).

Notwithstanding the inseparability of wealth distribution and risk production, efforts to adequately distribute wealth in Indonesia have failed to anticipate and manage the distribution of the risk unintentionally produced by modernisation. The risk generated by modernisation is generally absent in the literature on democratisation in Indonesia, as it pays major attention only to the welfare dimension of democratic practices. Where existing analysis focuses merely on the dynamics related to public control over 
welfare - changing power relations, debate over who is entitled to such resources, how to equally manage and distribute resources, the imagination of 'welfare' the public wants to realise-it has proved inadequate to explain the dynamics of public control over risk as a logical consequence of attempts to gain control over resources.

This paper attempts to show that, despite the absence of analysis of risk politics in previous literature, it is indeed present in the practice of democratisation of Indonesia. Some democratic institutions, under the transformative democratic approach, have produced a high amount of manufactured-risk, making both inseparable elements. Hence, it seeks to capture the dynamics of modernisation risk politics as integral to welfare distribution in Indonesian democratisation since the beginning of the reform era. The connectedness of risk and democratic institutions that focus on welfare distribution issues paves a way to understand how democratic agencies and institutions respond to the ever-increasing modernisation risks they have produced. This is important, as the same risk can have quite different meanings for different people, depending on their age, gender, habits, type of work, information, education, and so on (Beck, 1992). Differences in perceiving risk and welfare lead to contentious politics - a field to which the democratic practices and institutions in Indonesia could contribute.

This paper aims to understand the role of democratic institutions and actors' will and capacity in defining risk as subject to a certain risk dipositif, to use Foucault's term, which highly characterises and conditions what is counted as 'risk', as well as who is considered an 'agent' and 'institution' able to minimise the impact of risk. The dispositif is followed by certain technologies of government that represent the realisation of a certain rationality of risk. That said, the current lack of analysis of risk distribution should be captured as a product of such a dispositive, which plays a role as a hegemonic rationality defining risk. Here, the relatedness of power and knowledge becomes increasingly relevant, considering that some with dominant perceptions work only by utilising certain 
power and, at the same time, produce power that excludes other marginalised perspectives on risk.

As this paper assumes that everyone is unavoidably exposed to risk, the gap between those who can produce and consume knowledge about risk depends on how democratisation can capture the process of institutional and structural changes, as well as actors' capacity, knowledge, and experience maintaining and developing democratic infrastructure to bring about equality in the politics of risk. This paper will analyse the dynamics of the politics of knowledge, or dispositif, among actors and within institutional frameworks that might facilitate or constrain actors in producing their own knowledge and minimising their degree of exposure to such risk.

\section{Risk Society, Governmentality, and Transformative Democracy: A Review}

\section{Risk and risk society: the main features}

Ulrich Beck introduced the concept of risk and risk society in his seminal work, Risk Society: Towards a New Modernity (1992). Also known as manufactured-risk, risk can only be risk if it exists in the industrial context, includes human activity, and represents the probability of physical harm due to given techno-economic productivity or processes. It is decision-contingent, generated from the practices of people, firms, state agencies, and politicians (Beck, 1992). It differs fundamentally from threat, as it presupposes human decisions and human-made futures, including probability, technology, and modernisation.

Risk is not akin to catastrophe, but rather anticipation to catastrophe. That said, it is not actual, but the global staging of the act and the political anticipations, actions, and reactions that respond to the conditions in the world today (Beck, 2009). It is not 'real', but 'becoming real; it is not happening, but might be happening (Adam, Beck, \& van Loon, 2000). It is also associated with future 
outcomes (Lupton, 1999), and thus is invisible and remains more or less uncertain. Since risk is always of a future event that may occur, the anticipation of it obliges us to take preventive action. Hence, risk becomes 'real' in the sense that it shapes our present world, changes our perspectives, shapes our expectations, and guides our actions.

Considering the characteristic of risk, the most crucial question must be: how is the presence of future catastrophe 'manufactured'? (Beck, 2009). This question examines how the ways to analyse the future and anticipation of it are believed and condition our society. Because risk focuses on possible events that could occur, but need not necessarily occur, it is known with a high degree of unreality. Unknown and unintended consequences, thus, have come to be dominant forces in history and society (Beck, 1992; Mythen, 2004). People do not deal with catastrophe: they deal with something that has not yet become real, and which they want to prevent from becoming real (Beck, 2009). The material effects of risk are unavoidable, and dominate the socio-political landscape: everyone is living equally in the embrace of risk society, and is exposed to risk regardless of various social attributes.

Risk in late modernity differs from wealth, as it evades human perceptive abilities and alludes the control and protective institutions of industrial society (Beck, 1994). It creates systematic and irreversible harm, remains invisible, is based on causal interpretations, and thus only exists in terms of (scientific or antiscientific) knowledge about it (Beck, 1992). It is an object to be dramatised, magnified, or minimised within knowledge, as it is open to social redefinition and construction.

Here, risk is a social construct, with definitions based upon corresponding relations of definitions (Beck, 2009). It represents various rationality claims, between those who produce and consume certain risk definitions, and is the most prominent character of risk society. These relations also cover regulations, institutions, and capacities that structure the way actors identify and value risk, including legal matrices, epistemologies, and cultural-political 
settings that organise risk politics empirically (Beck, 2000). This departs from the assumption that the more objective and less calculable risk appears, the more its reality depends on its cultural perceptions in specific contexts. Beck even terms this the "clash of risk culture".

Knowledge gains a political significance, and the political potential of risk society must elaborate the diffusion of knowledge about risk. The social and economic legacy of knowledge grows along with the power over the media to structure and disseminate knowledge. As risk was invisible, the politics of knowledge about it determined its existence. Although Beck has admitted that it is not clear whether it is risk that has intensified or our view of it, Beck argues that both sides condition and strengthen each other: it is cultural perception and definition that constitutes risk (Beck, 2000). Indeed, Beck argues that the new risk has a real core-an objective reality. However, the epistemological and 'ontological status' of risk has been a contentious point in the reception of Becks' theory (Rasborg, 2012). Risk is risk in knowledge and within knowledge relations - public perception of risk and risk are the same and inseparable. In other words, risk is 'real' and constituted by social perception and construction.

Knowledge of risk will depend on ones' culture and social fabric of knowledge. Thus, in class positions, being determines consciousness, while in risk positions, consciousness (knowledge) determines being (Beck, 1992). The type of knowledge, including the experience and degree of dependence on knowledge, will influence the way people define risk. This will be different in various spatialtemporal contexts and will also be contested at both the individual and social level (Caplan, 2000). Being aware of that, it is impossible to pursue one single definition of risk, as it will ignore its changing context-how it is constructed and experienced through everyday interactions.

In this sense, Beck argues that defining risk must be reconstructed as a struggle between rationality claims. One cannot 
blame the hierarchy of credibility, but one can ask how certain perceptions and rationalities of risk are believed and arise socially, as well as how it is defined, redefined, diminished, and acquired. The tension between rational-scientific determination, which is usually brought by technical or professional experts, and irrational perception of risk increases.

\section{Power/knowledge over risk: dispositif as critique}

Despite its seemingly wide acceptance, the concept of risk society has been increasingly subject to criticism. Numerous literatures, specifically those using the governmentality perspective of Michel Foucault, have begun to criticise several of Beck's notions, but also develop them through the interplay between powerknowledge in risk management.

Aradau and van Munster $(2007,2008,2011)$ argue that Beck's work pertains to a specific approach to modernisation and role of knowledge, which does not adapt well to current practices and technologies of risk. They also propose that Beck's work has difficulty locating the threshold between early and reflexive modernity, and argue that Beck's work perceives risk as having the same features in all time - risk is independent of the sphere in which it is articulated (Aradau \& van Munster, 2007). Here, Beck seems to deny the existence of other notions of risk and exclude the fact that governing by means of risk has changed over time due to different types of knowledge, rationalities, techniques, and locales.

Using the notion of governmentality, their work presents a 'governmental dispositif of risk'. They suggested to see risk as a 'dispositif' or a heterogeneous assemblage of discursive and material elements for governing social problems, focusing on how presumably incalculable catastrophic risks are governed and arguing that "the identification and management of risk is a way of organising reality, taming the future, disciplining chance and rationalising individual conduct" (Aradau \& van Munster, 2008). Risk as dispositif is made 
up of a systemic combination of rationalities and technologies that create specific relations to the future: monitoring the future to calculate what the future can offer and to control and minimise its potentially harmful effects. Rationalities perform as knowledgeable discourses that represent objects of knowledge, confer identities and agencies upon social and political actors, and identify problems to be solved, while technologies represent the means of realising rationalities, aimed to manipulate the social and physical world according to identifiable routines. Both rationalities and technologies affect behaviour and construct forms of ordered agency and subjectivity in the governed population as part of the social problems identified (Aradau \& van Munster, 2007). A dispositif of risk is subject to modification, depending on the knowledgeable representation of the problems and objects to be governed and on the technologies available to produce particular effects among the governed.

Nonetheless, Dean $(1998,1999)$ proposes an alternative perspective to risk, stating that 'the genealogy of risk is much more complex than the theory of risk society allows' (Dean, 1998). He argues for seeing risk through a differentiated theoretical model, with risk connected with a range of complex technologies and practices (Rasborg, 2012). Instead of assuming risk as coming from a type of instrumental rationality, he suggests analysing risk rationalities as not only multiple, but heterogeneous, with practices for the government of risks assembled from diverse elements (Dean, 1998). Risk is a way, or rather, a set of different ways, of ordering reality, of rendering it into calculable forms so that it might be made governable in particular ways, with particular techniques and for particular goals (Dean, 1999). Hence, Dean shows the benefit of analysing the concrete, empirical, specific types of risk rationalities and practices.

O'Malley (2004) echoes similar arguments, suggesting the development of a genealogical approach to risk and uncertainty that acknowledges their contingent nature rather than merely the effects 
of the inescapable 'logic' of modernity. Despite understanding risk as a unitary or monolithic technology, he proposes analysing risk as a complex category made up of many ways of governing problems, regarded as deployed in diverse ways in the governmental settings they are embedded into. He suggests focusing on, among other things, the ways risk - as a framework of government - creates new subjectivities and redefines relationships. He argues it is necessary to examine '[...] various ways in which risk might shape the kind of subject we are to be made into, the practices through which we well be expected to govern ourselves, and the ways we will be expected to imagine the world and prepare for the future'. Hence, risk-centred government assigns new responsibilities to subjects. He also proposes examining patterns or rationalities of governance. Numerous literatures highlight the correlation of changes in risk techniques with changes in broader political rationalities, such as the emergence of 'neo-liberalism'; 'we are in the midst of a political shift in which governments are deploying risk in changed ways'. Here, risk-based techniques become dominant because they function to intensify the effectiveness of power (O'Malley, 1992).

Using risk as a dispositif and analysing the ways of governing through it paves a way to utilise governmentality in understanding risk, focusing on how power and knowledge shape people's everyday perception of risk. Power is able to manifest itself by producing certain discourse to be internalised by individuals and ultimately guiding the behaviour of populations, thereby enabling individuals to govern themselves in 'freedom'. The exercise of power creates and causes the emergence of new objects of knowledge and accumulates new bodies of information: the exercise of power perpetually creates knowledge, and knowledge constantly induces effects of power (Foucault \& Gordon, 1977). Thus, it is impossible for power to be exercised without knowledge, and it is also impossible for knowledge to work without engendering power. Two important kinds of power are put into effect: the power of knowledge of the truth, in the form of discourse and rationality, and the power to 
disseminate this knowledge, in the form of specific technologies.

Hence, governing through risk embodies certain exercises of power in the politics of knowledge. The politics require a distinction between the mental and practical aspects of government (Rose \& Miller, 1992). While mental aspects should be understood as 'political rationalities', the practical aspects should be seen as 'technologies of government'. Political rationalities are made by 'discursive fields within which the exercise of power is conceptualised, the moral justifications for ways of exercising power by diverse authorities, notions of the appropriate forms, objects, and limits of politics', while governmental technologies are 'the complex mundane of programs, calculations, techniques, apparatuses, documents and procedures through which authorities seek to embody and give effect to governmental ambitions'. This is clear, as governments addresses the dimensions of history composed by the invention, contestation, operationalisation, and transformation of more or less rationalised schemes, programmes, techniques, and devices that seek to shape conduct so as to achieve certain ends; to govern is to presuppose the freedom of the governed, to acknowledge their capacity to act and to utilise it for one's own objectives (Rose, 2004).

\section{Risk dispositif and transformative democratic politics}

This article examines the transformative social-democratic that favours structural changes through transformative democratic reform. It assumes that the existing democratisation has been dominated by compromises between moderate elites, consisting of oligarchs from the Soeharto era and important businessmen in local areas who have appropriated public offices (Djani, Törnquist, Tanjung, \& Tjandra, 2017). This view combines the notions of agency, institutions, and structural conditions, as it assumes that Indonesia is experiencing an elitist democracy characterised by the marginalisation of mass organisations and civil society activists, which are basically fragmented, as well as by depoliticisation 
through privatisation and power transfer to technocrats/local elites. These elements must be realised simultaneously, as they are equally important to democratisation.

The work of Harris et. al (2004) supports this view by arguing that democratisation must combine analysis of the balance of power with the ways actors try to master and alter conditions by employing and developing, or avoiding and undermining, democratic instruments in local and non-local political spaces. This view departs from the argument that the development of democracy has been depoliticised, and hence democracy is more than the existence of formal institutions and democratic rights, but must be substantive and able to consider the power relations underlying the local politics and use of democratic institutions. Törnquist \& Warouw (2009) echo similar propositions: the fundamental problem lies in the growth of democracy, which is rooted merely in pact making and institution building among elites. This excludes the views of the majority population from the formal political arena. As a result, the power to organise economic and political affairs rests primarily on the state and private businesses. Here, the depoliticisation of democracy represents the underdevelopment of autonomous political relations between the state and people. Democratisation could be advanced by encouraging popular influence and capacities to exercise control over public affairs, reconstruct the structure of power, create more alternative processes and agents of change, and improve policies and governance. Democracy is a matter of politics of representation based on three pillars; the people, the public matters, and the intermediary ways to exercise popular control.

Stokke \& Törnquist (2013), as well as Törnquist (2013), argue that transformative democratic politics acknowledges the need for substantive and extensive democratisation, a process that will work towards improved popular control of more widely defined public affairs on the basis of political equality. Hence, it is pertinent to initiate political agendas, strategies and alliances that use formal and minimalist democracy in order to introduce politics and policies 
that may enhance peoples' opportunities for improving democracy and making better use of it.

This article would use the basic components of democratisation presented by Törnquist and Warouw (2009) as its explanation: institutions, will, and capacity. In regards to these components, three requirements are central: first, the existence of standardised democratic institution related to (1) constitutionalism, including citizenship, law, and rights; (2) representative and accountable government; and (3) democratically oriented civil society and direct participation (Priyono, Samadhi, Törnquist, \& Birks, 2007). These components are universally valid as required tools to advance various democratic ends. Second, the existence of dynamic perspectives is related to how the main actors in democracy link to and deal with democratic institutions. This can be recognised by analysing some main and alternative actors in specific context, and by examining how these actors link to available democratic institutions. Third, actors have the ability, not merely will, to make use of, advance, or appropriate various democratic institutions.

In this regard, this article argues that the three components of democratisation are situated by a certain dispositif of risk; in other words, the existing reality of democratisation is indeed subject to certain political rationalities and technologies of government in regards to risk. To propose this argument is to acknowledge that institution and actors' will-capacity in democracy is not independent from certain power relations underlying local politics and the use of democratic institutions. This is prominent in avoiding certain forms of depoliticisation, which often leave democratisation a mere ritual of formal institutions and rights. Hence, this article attempts to bring democratisation to its core substance, considering power relations as an underlying context that highly characterises the democratisation process.

As Indonesia's democratisation concerns the issue of welfare, the presence of risk is inevitable. However, despite seeing risk as merely an unintended consequence, this paper argues that the 
politics of risk knowledge, which embodies certain power relations, situates the current condition of democratisation and its focus on welfare distribution. The consideration of risk creates specific political configurations that condition the practice of distribution of wealth. Thus, most important here is to analyse what is counted as 'risk', what is excluded, and what kind of power relations are at play. This analysis is followed by certain knowledge of 'actors' that are considered relevant in defining risks, and 'institutions' that are considered legitimate in institutionalising and minimising risk. The analysis of relevant actors will help us examine the kind of identities and subjects that actors are made into, and specific institutions as technologies that situate actors in governing themselves.

Analysis of efforts to expand water access and increase oil palm plantation in Pandeglang gains its relevance here. The decision to expand the number of oil palm plantations is better understood as a product of a certain dispositif towards modernisation risk. In other words, palm oil production embodies certain rationalities towards risk and acts as programmes or technologies through which power over risk knowledge is exercised. Hence, oil palm plantations in Pandeglang have been built in an effort to overcome a certain 'risk' in the existing dispositif. In this construction, both institutions and actors' will-capacity are 'hijacked' by a certain knowledge of risk that defines what knowledge is relevant to consider, what actors can relevantly participate with specific identities and subjectivities, as well as which institutions act as technologies of government. However, in the attempt to deal with risk, plantations end up producing various other knowledges of risk, with different actors attempting to compete with the existing dispositif underlying the process. Examining the power relations at play in rationality claims and the political technologies of the plantations is necessary to formulate ways to encourage public control of welfare and risk, specifically by intervening in the level of rationality and technologies of government. 


\section{Risk and Welfare Politics: Expanding Water Access Amidst Massive Palm Oil Production}

This sub-chapter attempts to understand the power-knowledge relations in the politics of risk by analysing efforts from civil society to expand access to clean water, despite the growth of oil palm plantations in Pandeglang District, Banten Province, Indonesia.

\section{Lack of water access as risk in southern Pandeglang}

Palm oil production highly characterises the condition of water governance in the southern part of Pandeglang. Not only do the characteristics of palm oil affects the amount of available water, but the expansion of plantations also leads to massive reductions of water springs. As plantation areas are mostly located in the southern part of the district, the problem of water access is experienced significantly by the society of the area, with the 'village' as their basic political institution. This sub-chapter shows that, despite the massive, national narrative of economic development manifested in the palm oil industries, the local residents in Pandeglang, specifically in Sindangresmi and Picung sub-districts, perceive risk and oil palm plantations in accordance with their daily experience of limited water access. These two sub-districts are areas where oil palm plantations have mushroomed.

Since the early 2000s, local communities in both sub-districts have faced difficulty accessing clean water from underground springs. They are aware of the effects of the palm oil industry in their area, including the degradation of soil quality and reduction of available ground water, which is used by thousands of people for drinking, food, and sanitation purposes. The erosion of water quantity and quality has become one risk associated with palm oil cultivation in Pandeglang.

Palm oil industries have had the greatest impact on the availability sustainable water resources in both sub-districts due to its large scale, which has caused changes in land use, significantly 
reduced the area of the water ecosystem, and created substantial changes in the social-ecological system (Merten et al., 2016). Several issues have arisen. First, in both sub-districts, local farmers face difficulties working their rice fields. The agricultural sector has to rely on rainwater, because the oil palm plantations desolate the soil and impede the creation of water reserves. Second, in terms of gaining profit and economic growth, local residents argue that palm oil industries cannot benefit them. They have no access to employment within the industries due to the limited number of human resources needed. While rubber plantations, which dominated the local livelihood before oil palm plantations began mushrooming, required at least two to three workers per plot, oil palm plantations only need two workers to manage and work ten hectares of land. In other words, rubber plantations had created more employment opportunities for local communities. As a result, local residents are not involved in and are even disengaged from palm oil production. This is also related to the low wages paid to palm oil workers, who earn only $\mathrm{Rp} 12,500$ for a half-day of work. Third, due to the massive changes in land use instigated by palm oil industries, local communities do not possess their own land property and do not have the chance to plant any trees for timber. This affects the water debit, which may reduce the availability of water for their basic needs.

The decreased availability of water availability caused by palm oil production has affected local water governance in both sub-districts. First, due to the characteristics of the industry, local governments require significant funding to use deep water drilling mechanisms, as water is no longer found at normal depths and cannot easily be pumped out. In Cempakawarna Village, for example, the local community can only find polluted, feculent water after 30 metres of digging. They are not able to use this water, due to its poor quality, and must thus dig up some 150 metres in order to reach clean water. Second, it is also necessary to construct check dams to decrease streamflow velocity, which can promote water 
conservation and ensure that the circulation of water to charge local communities' wells. Third, there is a need to craft water treatment technologies that can process raw, feculent water into clean water. Although the Regional Drinking Water Company (PDAM) of Pandeglang has promoted this technology in several areas, it is not widely used due to its high cost. Since PDAM has yet to expand the coverage of its piped-water system to these two sub-districts, specific strategies are required to ensure clean water access even as the availability of water is limited by oil palm plantations. Hence, these three technologies condition local water governance in ways that provide specific constraints in providing water access, direct actors' decisions, and situate their engagement.

The lack of clean water access has become one of the greatest risks that local communities have encountered. They strive to avoid scarcity, both short-term and long-term. This situation conditions their positions and attitudes towards palm oil industries as entities that they perceive as sources of risk. In other words, having water access is a daily problem they have to deal with, and thus those opposing to oil palm plantations propose different ways of seeing what is considered risk and its sources.

\section{Palm oil industries as development catalyst: risk dispositif}

Oil palm plantations in Pandeglang currently cover around 2,744 hectares. Produced and distributed in the form of Fresh Fruit Bunches (FFB), the planted areas of small-holder estates increased from $3,814.30$ ha in 2015 to $3,817.80$ ha in 2016. Total production was 4,220.28 tonnes in 2015, spread across such sub-districts as Cikeusik, Munjul, Angsana, Sindangresmi, and Picung-all of which can be labelled as geographically in the southern part of Pandeglang. The industries were run in the Sanghyangdamar area of oil palm plantation, which has been under PT Perkebunan Nusantara (PTPN) VIII since 1996. Before the total introduction of palm oil commodities and plantations in the 1990s, the area was predominantly used for rubber cultivation. 
Table 1. Historical development of PTPN VIII in Pandeglang, Banten

\begin{tabular}{|l|l|}
\hline Year & Activities \\
\hline 1915 & $\begin{array}{l}\text { Established under Dutch colonial government as N.V. Coy En } \\
\text { Cooster }\end{array}$ \\
\hline 1942 & Under supervision of Japanese occupation government \\
\hline 1957 & $\begin{array}{l}\text { Nationalisation by Indonesian government, including the area of } \\
\text { Sanghyangdamar in the Group of New PPN: Jabar V }\end{array}$ \\
\hline 1972 & Status of PN Perkebunan changed to PT Perkebunan \\
\hline 1978 & $\begin{array}{l}\text { Sanghyangdamar in same working unit as Pasir Waringin } \\
\text { plantation }\end{array}$ \\
\hline $1985-1996$ & $\begin{array}{l}\text { Sanghyangdamar area became a separate working unit under PT. } \\
\text { Perkebunan XI }\end{array}$ \\
\hline $1996-$ now & $\begin{array}{l}\text { Sanghyangdamar area became a working unit under PT. } \\
\text { Perkebunan Nusantara VIII }\end{array}$ \\
\hline
\end{tabular}

Source: Overview of PTPN VIII, Kebun Sanghyangdamar Pandeglang, 1996

Palm oil industries have been perceived as pioneers in the development of rural, inland areas. Since palm oil cultivation emerged massively in 1980, it was intended to advance the agricultural sector and create the new economic growth hubs in rural areas that would reduce poverty rates. Up until now, palm oil cultivation is dominant in at least 31 Indonesian districts, developed by state owned enterprises or private companies as core plantations and local communities as nucleus/community plantations (Perkebunan Inti Rakyat/PIR) or other partnership schemes. The scheme is claimed to open access and turn local farmers into prominent actors in Indonesia's palm oil production. While rural areas are generally isolated and under-developed, oil palm plantations are perceived as solutions that might create significant employment opportunities through the development of cultivation factories, road and access infrastructure, ports, educational facilities, and economic facilities. Through the introduction of palm oil industries, rural areas are expected to contribute to the development of local and national economies. The growing production of Crude Palm Oil (CPO), for 
example, has had positive and significant impacts not only on the growth of gross regional domestic product, but also gross domestic product. This has triggered a massive enhancement in palm oil production, with governments seeking to better advance local economies rather than $\mathrm{CPO}$ production. Hence, regional economies that are supported by palm oil production have grown faster than those which are not.

However, the expansion of palm oil industries in rural areas cannot be separated from national targets that project oil palm plantations as main sources of economic growth through export targets. Nationally, oil palm-planted areas have increased considerably, from 300,000 ha in 1980 to 16.1 million ha in 2018 , with total CPO production also increasing from 700,000 tonnes in 1980 to 33.5 million tonnes in 2016 (GAPKI, 2018). Palm oil has become a source of livelihood for 1.5 million smallholder farmers and engaged up to 8.2 million workers. In terms of palm oil production, Indonesia has become a global leader, exceeding its neighbour Malaysia. Of the total 64 million tonnes of palm oil produced globally, Indonesia contributes more than 35 million tonnes, or some $54 \%$ of global production (Ministry of Agriculture of Indonesia, 2017). By dominating the supply chain, starting from raw materials to final products, Indonesia is perceived as being highly competitive through its inclusion of $87 \%$ of domestic components.

Indonesia's national government, especially under President Joko Widodo, has introduced various strategies to realise this potential. First, Indonesia is using the Indonesia Sustainable Palm Oil (ISPO) scheme, which positions the industry as a significant contributor to Indonesian foreign exchange by increasing exports. The production and export of palm oil-in the forms of CPO, Palm Kernel Oil (PKO), oleochemical, and biodiesel-for example, showed positive growth between July and August 2018, with monthly volume hitting a record of 3.22 million tonnes; this was a $27 \%$ rise from the 2.54 million tonnes produced in July 2017 (Indonesian Palm Oil, 2018). Exports account for $70-75 \%$ of production, while 
$20-25 \%$ is used for domestic consumption (GAPKI, 2018).

Second, to reduce Indonesia's dependence on the global CPO market and to add value to the product, Indonesia has been encouraging the downstream of palm oil products since 2011 through three schemes: downstreaming the oleofood industry, oleochemical industry, and biofuel. These downstreaming programmes were initially aimed to accelerate the development of Indonesia's economic sector. The export of palm oil-based downstream products has become one of the most significant contributors to Indonesia's foreign exchange and plays an important role in strengthening the rupiah against foreign currencies (Barus, 2018).

Third, Widodo specifically has used palm oil industries as resources for advancing national economic growth and attempted to enforce the principles of deregulation and debureaucratisation in the process. The principles were initially aimed to strengthen liquidity, foster the development of real sector economy through structural reform, and ensure legal and business certainty. Here, the government has strived to eliminate possible obstacles that might hinder business and economic activities, as well as to create a conducive environment for foreign and domestic investment by ensuring palm oil industries are not hampered by counter-productive regulations.

Palm oil production in Pandeglang, as a proxy to the narratives and technologies in the national context, is considered a 'catalyst', a strategy to enhance economic development in local and national contexts through the acceleration and spurring of local residents' economic activities and through various employment schemes and infrastructure buildings. Through plantations, the government offers numerous legal incentives while palm oil investors provide employment opportunities, technology transfers, infrastructure developments, and contributions to local and national economies. Palm oil production, in this regard, is a must: it is a remark on society's need for progress and better living, for developing better livelihoods and distributing welfare to the rural poor. As such, the 
industry, with its aim to distribute wealth, focuses on the process of modernisation. Since the main issue is to distribute socially produced wealth in a socially unequal and legitimate way, industries work with the positive logic of acquisition and are characterised by the ownership of basic material needs despite scarcity.

In other words, palm oil industries in Pandeglang work under the rationality of economic development, which favours increased national economic growth and functions as a technology of governing this rationality. The industries are part of a development programme, a result of advanced modernisation, which is claimed to be executed for the interests of the public as a whole-i.e. for economic growth and public welfare. What is considered 'risk' by the industries is related to decreased growth, specifically at the macro, national level, which is considered to affect the progress of economic development as well as those at the local level. Government plans to increase the number of palm oil products have been intended to avoid this risk, which might increase the level of poverty among local residents. This notion of risk is widely accepted at the national and local levels, and performed as a 'universal' end that should be achieved and encouraged by all stakeholders. The national government has issued Government Regulation No. 72 of 2014 on the Increase in Government Capital Share to PTPN III as a state-owned plantation company. Together with the Widodo regime's three previous efforts to advance palm oil industries, this regulation also works as a political technology that situates the enhancement of national economic growth and conditions the regime of truth within society in regards to progress. Since profit and macro-economic development have become priorities and logics that govern society, this narrative and technology has to push aside the local communities' interest in clean water.

Contentious politics of risk: actors and democratic institutions in expanding water access

Referring to the list of 32 basic democratic institutions brought by Törnquist and Warouw (2009), it is important to note 
that only some are directly relevant to the issue of welfare and risk, namely (1) equality of citizens, (2) right to get work or engage in productive employment, access social security, and other basic needs, (3) transparency, accountability, and democratic practice in civil organisations, and (4) access and broad participation in public affairs among all social groups. These institutions are argued as subject to contingency due to the ever-changing power relations in risk politics.

In this regard, democratic institutions and actors perform as sites of struggle between rationality claims about risks; between risk dispositif. As for actors, the configuration of stakeholders considered 'relevant' to participate, involve, and craft solutions is different for each dispositif. Similarly, for democratic institutions, the function and degree of compliance of each element varies due to the tension between the dispositif.

\begin{tabular}{|c|c|c|}
\hline & Dispositif & Alternative \\
\hline Risk & $\begin{array}{l}\text { Underdevelopment; national } \\
\text { poverty }\end{array}$ & $\begin{array}{l}\text { Scarcity of water for daily } \\
\text { uses }\end{array}$ \\
\hline Rationality & $\begin{array}{l}\text { Progress, modernisation, and } \\
\text { national, long-term economic } \\
\text { growth }\end{array}$ & $\begin{array}{l}\text { Local, daily subsistence of } \\
\text { clean water }\end{array}$ \\
\hline Solutions & $\begin{array}{l}\text { Massive economic } \\
\text { development through, among } \\
\text { others, investment in the palm } \\
\text { oil sector }\end{array}$ & $\begin{array}{l}\text { Absence of palm oil } \\
\text { industries, procurement of } \\
\text { water infrastructure and } \\
\text { access }\end{array}$ \\
\hline Technology & $\begin{array}{l}\text { Palm oil industries in rural } \\
\text { areas, Government Regulation } \\
\text { No. } 72 \text { of } 2014 \text { on the Increase } \\
\text { in Government Capital Share } \\
\text { into PTPN III }\end{array}$ & $\begin{array}{l}\text { Collective mechanism in } \\
\text { the procurement of water } \\
\text { access: grant from Qatar } \\
\text { Charity, temporary wells, } \\
\text { warm hose facilities, } \\
\text { retention basins from Village } \\
\text { Funds, demonstrations and } \\
\text { negotiations }\end{array}$ \\
\hline
\end{tabular}




\begin{tabular}{|l|l|l|}
\hline & Dispositif & Alternative \\
\hline Relevant actors & $\begin{array}{l}\text { Government in national, } \\
\text { regional, sub-regional, } \\
\text { and village level; palm oil } \\
\text { companies }\end{array}$ & $\begin{array}{l}\text { Government in national, } \\
\text { regional, sub-regional, } \\
\text { and village level; palm } \\
\text { oil companies; rural poor } \\
\text { communities; local NGOs }\end{array}$ \\
\hline $\begin{array}{l}\text { Projected } \\
\text { subjectivities }\end{array}$ & $\begin{array}{l}\text { Prioritise and contribute } \\
\text { actively in long-term national } \\
\text { economic development }\end{array}$ & $\begin{array}{l}\text { Prioritise and contribute } \\
\text { to advance clean water } \\
\text { provision for day to day } \\
\text { basis }\end{array}$ \\
\hline
\end{tabular}

The efforts of national government to mainstream the dispositif have led to the existence of groups supporting and opposing oil palm plantations, both within and without local communities. These are products of identity formation as a consequence of the existing risk dispositif towards economic development. The groups supporting plantations ('pros') perform as those whose belief in modernity and the virtue of national-economic growth is manifested in the massive expansion of palm oil industries. Being under this dispositif grants them the identity of 'growth defender', of striving for public and national economic interests in the name of development. This, to some extent, also relates with their shared identity as Indonesians who are expected to actively bolster national efforts. Actors under this dispositif participate in numerous attempts to support development in the specific scheme prepared by the government and the industries, e.g. those who agree to the plantations and commit to involvement in limited employment opportunities. This participation is part of their identity and role in national development.

However, as the risk theories explain, "[...] the consequences and successes of modernization become an issue with the speed and radicality of processes of modernization" (Beck, 2006). Here, risk emerges because the basic institutions to calculate and minimise the unintended consequences of modernisation have collapsed. In other words, the dangers produced by modernisation and industrialisation can no longer be controlled by institutions, causing irreversible harm 
to nature and humanity. As the palm oil industries in Pandeglang grow, the risk produced by the plantations will also increase and affect basic livelihood, especially the availability of water resources. The amount and availability of existing clean water resources in Pandeglang, specifically in the rural "southern" areas, has decreased significantly in the last two decades.

While the dispositif in palm oil industries posits poverty and low development levels as risks to be avoided, with palm oil production as a solution, the groups opposing oil palm plantations ('cons') —although also assuming 'poverty' as a risk-perceive the industries as sources and causes of risk. The cons strive to promote clean water scarcity as 'alternative risks' as well as knowledge to assess palm oil expansion. Alternative, here, means another view towards what is counted as 'risk', including actors and mechanisms that are perceived as relevant to minimise and deal with such risks. Having exposure to the idea of local welfare through water fulfilment, the cons might be labelled as against public interests or national development. While the pros refer to macro and national economic development as ways out of poverty in the long-term, the cons argue for the procurement of clean water-something hindered by palm oil production - as a source of livelihood. For them, any attempts to eliminate the water sector will be detrimental at the local level in the short and long term. Their reliance and dependence on the water sector, in this regard, highly characterises the way they consider risk and its sources. Hence, for the cons, it is important to analyse the risk produced by the palm oil industries, which they see as created by the government's decision to invest in the sector and bring southern Pandeglang to a new level of development, thereby transforming its whole economic and social structure over the long term.

As for democratic institutions, it is apparent that citizen equality, transparency, and broad participation are situated perceived as relevant. Here, knowledge regarding the lack of water sustainability as a risk is initiated by various practices that 
are exclusionary to local communities in the emergence of palm oil industries in Pandeglang. When transforming from rubber to palm oil commodities in the 1990s, there was no discussion or socialisation from the company and local government in regards to the transformation in land use, specifically to address the status of the nucleus estate and rubber smallholders. Local communities have no access to information regarding the current status of the land or the period of concession. There is also no CSR mechanism from this state-owned enterprise to address the issue of water provision. They only have to deal with the expansion, and have no channel to voice their aspirations for water access. In the existing dispositif towards economic growth, local communities at the village level lack space; as they are seen as unable to contribute significantly to palm oil production, they are considered not significant or beneficial to achieve national, macro-economic targets. Since they have been perceived as less relevant, their voices are not constitutive in the oil palm plantations.

In regards to this issue, local communities in Sindangresmi and Picung sub-districts - supported by a student organisationconducted demonstrations and negotiations with PTPN VIII in 2003. They met with several company employees and delivered their demands regarding water resources. They strived to break through 'boundaries' and become and relevant, specifically by requesting the procurement of five drill points and five pieces of sanitation infrastructure for their water needs and community welfare. However, since they had only discussed with technical workers and had been unable to meet those with higher and more significant positions in the company, several of the deals achieved in the forums could not be realised.

This condition also corresponds with their rights to social security and other basic needs. In claiming these rights, local residents were aware that water provision was still an issue that depends highly on stakeholders' political decisions. Several villages listed as priorities for inclusion in the regional government's water 
provision programme, namely the National Rural Water Supply and Sanitation Project (PAMSIMAS), have been determined by high politics, specifically by the priority and political preferences of the regent. Through this mechanism, the various sub-districts that are in dire need of clean water do not always gain the regional government's recommendation to get water support from the national government. The basic requirements for the programme are also irrelevant to the conditions of Sindangresmi and Picung sub-districts, namely the availability of water idle capacity. Since these areas lack water springs, they do not have sufficient resources for the programme. As such, political negotiation with actors to reform basic requirements have been prominent. However, the difficulties they face and their relatively low bargaining position has led them to be sceptical about the notion of 'rights' and the government that had been expected to protect them. In Cigarunggung Village, the majority of the local community has no clue about the rights members can claim, leading them to create a collective mechanism that would ensure access to water.

First, local communities have been using funding from Qatar Charity since 2013. This donor programme includes funding assistance from the government, NGOs, and local communities of Qatar, especially for building mosques and water wells in various villages. In 2018, three mosques and twenty water wells were built in these two sub-districts. Although the aid covers only the procurement of water pumps and other well equipment, local communities have found the assistance to be very important in advancing their access. They are now attempting to craft other funding schemes to support the procurement of water drills.

Second, local communities strive to build temporary dig wells and worm hose facilities. Since social bonds among neighbours in the villages remain strong, and the annual water tank support from the government in the dry season barely reaches the area due to various road infrastructure issues, they have built collective mechanisms to raise funds for digging communal, temporary 
excavation wells. All residents of the villages can take water from these wells for their daily needs. Some households with individual resources also might distribute water from their bucket wells to residents in their neighbourhoods. In doing this, they may use small worm hose facilities to make the water flow from the bucket wells to their homes. The worm hoses are small, tiny hoses (1-2 mm in diameter) that connect water storage buildings or individual bucket wells to water containers at the household level. Local residents have to individually cover the cost of installing and managing the worm hoses.

However, the dispositif of economic development-which leads residents to be sceptical of the government-has also been challenged by local communities' need to be involved and have the government and palm oil companies fulfil their needs. In this case, local communities strive to make use of systems and political technologies to benefit them in terms of water access. They have produced collective strategies to ensure regional programmes, especially retention basins, meet their water needs. The regent of Pandeglang issued Regional Regulation No. 42 of 2015 on the Procedures for Managing Village Funds, which prioritises, among other things, the construction of retention basins as sources of water and the development of clean water management at the village level. The construction of retention basin for each village represents these concerns. The basins are expected to support local residents' agricultural activities and hold clean water reserves for the dry season. However, the amount provided by the Village Funds can only cover the construction of physical water basins, and are unable to ensure the procurement of clean water. While sources of water for basins may vary - mountain springs, rainwater harvests, or sewer water - most of the basins in southern Pandeglang can only rely on rainwater. That said, residents have difficulties finding water for basins during the dry season, and hence leave the basins unfunctional. Being aware of this, they strive to apply for funding from the central government through grant programmes that subsidise 
the procurement of water for basins. The head of Cempakawarna Village, for example, has also raised funds to turn the basins into public spaces and local tourism destinations, thereby supplementing the village income and supporting the construction of water excavation points that may ensure sustainable water access.

The residents also strive to advocate for a greater scheme for clean water provision through Village Funds. In both sub-districts, residents have argued that the allocation of Village Funds has not been able to meet local demands or recognise the empirical conditions of local communities. Programmes procuring bicycles and waste banks for villages through the Village Funds, for example, are seen as unnecessary for residents' needs. However, village governments may be penalised if they do not include such the programmes in their Village Fund schemes. In this regard, local communities strive to negotiate with their village governments to expand the budget for building excavation points and checking dams. Through villagelevel Development Planning Meetings (Musyawarah Perencanaan Pembangunan/Musrenbang), residents also aspire to apply for funding through the state, provincial, and district budgets.

Additionally, Bungur Copong Village has also been able to find and make use of unused water springs within palm oil areas. Residents have collectively proposed seeking funding assistance from the Department of Agriculture of Pandeglang for procuring pipeline systems and storage buildings in the village. Such pipeline systems function to carry water to storage buildings and to residents' agriculture fields. Although the water debit is relatively small and cannot be used in the dry season, local communities still strive to manage their water. Through self-help mechanisms, local communities also contribute both in-cash and in-kind to making and maintaining these water systems. 


\section{Conclusion}

The twenty years of Indonesia's democratisation to date should be understood as a never-ending struggle over rationality claims and technology as ways to equally distribute welfare for all citizens. In other words, welfare and risk distribution is highly characterised by struggle over rationality claims and technologies of governing for supporting such risk. This paper has shown that democratic institution and actors perform as sites of contention between rationality claims towards risks; between risk dispositif. As for actors, the configuration of stakeholders considered 'relevant' to participate in, become involved in, or craft solutions is different for each dispositif. Similarly, the function and degree of compliance to each democratic institution vary due to the tension between the dispositif.

As this paper has shown, the contradictive movement between expansion of palm oil production and of water access for local communities has been a product of tension between (1) the dispositif which perceives national poverty as a risk to be handled through palm oil industries, and (2) the knowledge that prioritises water needs for local communities' daily subsistence. Although actors and institutions are situated by the dispositif which constrains local communities to fulfil their aspirations, their political agency eventually leads them to appropriate existing technologies for meeting their own water needs. Local communities are governed and exposed to the dispositive, yet at the same time there are limits to such governmentality of risk.

Understanding democracy as ever-changing tensions between rationality shed lights both on the effort of governing society through risks as well as crafting possibilities for countering and challenging such rationality. Acknowledging the empirical reality that democratic institutions might be situated by a certain dispositif of risk, this paper is not intended to undermine the virtue of transformative democracy as an approach to evaluating Indonesia's 
democratisation. Nevertheless, it is important to recognise the possibility of changing the configuration of power, of knowledge, and of technologies, thereby broadening the chance for certain institutions to work more inclusively and for various actors to make use of such institutions. This affects not only the democratic institutions that are considered relevant, but also the configuration of relations between actors and these institutions. The work to optimise democratic institutions and to maximise the merits of actors' will-capacity is political in character, requiring a spatialtemporal analysis of the specific configuration of power that will allow or constrain such continuous efforts. 


\section{References}

Adam, B., Beck, U., \& van Loon, J. (2000). The risk society and beyond: critical issues for social theory. London: SAGE Publications ltd. doi: $10.4135 / 9781446219539$

Aradau, C., \& van Munster, R. (2007). Governing terrorism through risk: taking precautions, (un)knowing the future. European Journal of International Relations, 13(1), 89-115. https://doi. org/10.1177/1354066107074290

Aradau, C., \& van Munster, R. (2008). Taming the future: the dispositif of risk in the war on terror. In L. Amoore \& M. D. Goede (Eds.). Risk and the war on terror (pp.23-40). London, New York: Routledge.

Aradau, C., \& van Munster, R. (2011). Politics of catastrophe: genealogies of the unknown. London, New York: Routledge.

Barus, H. (2018). Hilirisasi industri sawit percepat pertumbuhan ekonomi. Industrycoid. Retrieved from http://www.industry.co.id

Beck, U. (1992). Risk society: towards a new modernity. London; Newbury Park, California: Sage Publications.

Beck, U. (1994). The reinvention of politics: towards a theory of re $\square$ exive modernization. in U. Beck, A. Giddens and S. Lash (Eds.). $R e \square$ exive Modernization (pp.1-55). Cambridge: Polity Press.

Beck, U. (2000). Risk society revisited: theory, politics and research programmes. in B. Adam, U. Beck, \& J. van Loon (2000). The risk society and beyond: critical issues for social theory (pp.211-229). London: SAGE Publications Ltd. doi: 10.4135/9781446219539, 211-229

Beck, U. (2009). World at risk. Cambridge: Polity Press.

Caplan, P. (ed.). (2000). Risk revisited. London; Sterling, Virginia: Pluto Press. Retrieved from http://www.jstor.org/stable/j.ctt18fsbr6

Dean, M. (1998). Risk, calculable and incalculable. Soziale welt: zeitschrift für sozialwissenschaftliche forschung und praxis, 49(1), 25-42.

Dean, M. (1999). Governmentality: power and rule in modern society (2nd ed.). London, Thousand Oaks, California: SAGE.

Djani, L., Törnquist, O., Tanjung, O. \& Tjandra, S. (2017). Dilemmas of populist transactionalism. Yogyakarta: PolGov Publishing.

Foucault, M., \& Gordon, C. (1977). Power/knowledge: selected interviews and other writings, 1972-1977 (1st American ed.). New York: Pantheon Books.

GAPKI Indonesian Palm Oil Association. (2018). Perkembangan mutakhir 
industri minyak sawit Indonesia. Retrieved from https://gapki. $\mathrm{id} /$ news/3971/perkembangan-mutakhir-industri-minyak-sawitindonesia

Harriss, J., Stokke, K., \& Törnquist, O. (Eds.). (2004). Politicising democracy: the new local politics and democratisation. Hampshire; New York: Palgrave Macmillan.

Indonesian palm oil export hit record high. (2018, 29 August). Retrieved from https://www.bpdp.or.id/en/berita/ekspor-minyak-sawitindonesia-catat-rekor-tertinggi/

Lupton, D. (Ed.). (1999). Risk and sociocultural theory: new directions and perspectives. Cambridge; New York: Cambridge University Press.

Merten, J., Roll, A., Tarigan, S., Hölscher, D., \& Hein, J. (2017). Expanding Oil Palm Cultivation in Indonesia: Changing Local Water Cycles Raises Risks of Droughts and Floods. Briefing Paper 1/2017. German Development Institute. Retrieved from https://www.diegdi.de/uploads/media/BP_1.2017.pdf.

Ministry of Agriculture of Indonesia. (2017). Kelapa sawit Indonesia semakin menjadi andalan ekonomi nasional. Retrieved from https://pse.litbang.pertanian.go.id/ind/index.php/22-informasiberita/228-kelapa-sawit-indonesia-semakin-menjadi-andalanekonomi-nasional.

Mythen, G. (2004). Ulrich Beck: a critical introduction to the risk society. London; Sterling, Virginia: Pluto Press.

O'Malley, P. (1992). Risk, power and crime prevention. Economy and Society, 21(3), 252-275. https://doi.org/10.1080/03085149200000013

O'Malley, P. (2004). Risk, uncertainty, and government. London, Portland: GlassHouse.

Overview of PTPN VIII, Kebun Sanghyangdamar Pandeglang, 1996.

Priyono, A. E., Samadhi, W. P., Törnquist, O., \& Birks, T. (2007). Making democracy meaningful: problems and options in Indonesia (1st ed.). Jakarta: Demos.

Rasborg, K. (2012). '(World) risk society' or 'new rationalities of risk'? A critical discussion of Ulrich Beck's theory of reflexive modernity. Thesis Eleven, 108(1), 3-25. https://doi. org/10.1177/0725513611421479.

Rose, N. S. (2004). Powers of freedom: reframing political thought. Cambridge: Cambridge University Press.

Rose, N., \& Miller, P. (1992). Political power beyond the state: problematics of government. The British Journal of Sociology, 43(2), 173. https:// 
doi.org/10.2307/591464.

Samadhi, W. P., \& Warouw, N. (eds.). (2009). Building democracy on the sand: advances and setbacks in Indonesia. Sleman, Indonesia: Jakarta: PCD Press; Demos.

Sørensen, M.P. (2018). Ulrich Beck: exploring and contesting risk. Journal of Risk Research, 21(1), 6-16. https://doi.org/10.1080/13669877. 2017.1359204.

Stokke, K., \& Törnquist, O. (eds.). (2013). Democratization in the Global South: the importance of transformative politics. Hampshire; New York: Palgrave Macmillan.

Törnquist, O. (2013). Assessing dynamics of democratisation: transformative politics, new institutions, and the case of Indonesia. New York: Palgrave Macmillan.

Törnquist, O. \& Warouw, N. (2009). Memahami demokrasi: beberapa catatan pendahuluan tentang konsep dan metode. in W.P. Samadhi \& N. Warouw (Eds.). (2009). Building democracy on the sand: advances and setbacks in Indonesia (pp.19-44). Sleman, Indonesia; Jakarta: PCD Press; Demos. 